\title{
Implementation of Islamic Civilization and Asian Civilization Course: Experience in National University of Malaysia and Private Higher Education Institutions towards Consolidating the Element of Science and Technology
}

\author{
Nazri Muslim ${ }^{1}$, Abdul Latif Samian ${ }^{2} \&$ Nur Hafilah Musa ${ }^{3}$ \\ ${ }^{1}$ Centre for Citra University, National University of Malaysia, Malaysia \\ ${ }^{2}$ Institute of the Malay World and Civilization, National University of Malaysia, Malaysia \\ ${ }^{3}$ Faculty of Law, National University of Malaysia, Malaysia \\ Correspondence: Nazri Muslim, Centre for Citra University, Universiti Kebangsaan Malaysia, Malaysia. E-mail: \\ nazrimuslim@yahoo.com
}

Received: May 5, 2015 Accepted: August 7, 2015 Online Published: August 18, 2015

doi:10.5539/ass.v11n22p116 URL: http://dx.doi.org/10.5539/ass.v11n22p116

\begin{abstract}
Islamic Civilization and Asian Civilization (TITAS) course at Public Higher Educational Institution (IPTA) has long been implemented in National University of Malaysia (UKM). In UKM, it is compulsory for all students to sit for TITAS paper, and this requirement is applied to both Muslim and non-Muslim students. This is different for students enrolled in Private Higher Educational Institutions (IPTS) where its operation is subject to the Private Higher Educational Institutions Act 1996, or known as Act 555 which serves to regulate the establishment, registration, management and supervision as well as the monitoring of quality of education provided by IPTS. Based on the provisions provided in Section 43, all IPTS should teach Malaysian Studies and Islamic Studies subjects for Muslim students and Moral Education subject for non-Muslim students. These subjects are known as Compulsory Subject (MPW) and must be taken by all students and are considered as must-pass subjects for graduating. Thus, after 15 years of MPW implementation, the Ministry of Education has revamped the structure MPW into General Subject (MPU). Among the goals of this new structure is to improve students' potential ability towards producing holistic students and homogenizing general education curriculum between IPTA and IPTS. This objective is achieved through the appreciation of philosophy, values and history, soft skills mastery, broadening of knowledge according the Malaysian way and the application of soft skills. Therefore, this article will discuss the Islamic Civilization and Asian Civilization course in the new MPU structure in IPTS in comparison with the IPTA. From the discussion, it was found that Islamic Civilization and Asian Civilization course has been applied in the MPU structure towards producing students who appreciate good values and identity. At the same time, suggestions were also presented, so that the elements of science and technology will also be adopted in Islamic Civilization and Asian Civilization course especially in matters regarding the roles and contributions of Science and Technology to world civilization.
\end{abstract}

Keywords: TITAS, science and technology, soft skills, private higher educational institutions, public higher educational institutions

\section{Introduction}

Efforts to produce Malaysians who meet the characteristics outlined in the National Education Philosophy have been ongoing. One of the methods adopted to achieve the National Education Philosophy is via the introduction of compulsory courses at university that are different from the core courses for each field. Hence, Islamic Civilization and Asian Civilization course has been introduced, made compulsory for all students of the IPTA and standardized throughout the nation. This has been followed by the Ethnic Relations course until today. However, in IPTS, it was only introduced after the existence of Higher Educational Institutions Act which is slightly different in IPTA in terms of the courses introduced. The Compulsory Course in IPTS presently includes 3 courses namely Malaysian Studies, Islamic Education/Moral Education and National Language. However, all these three courses were only made compulsory to local students whereas foreign students were exempted. The 
situation seems to create dualism in the national education system. Since all IPTS in Malaysia were operating under the consent and requirements of this country, then each IPTS concerned, regardless of its form, for as long as it is allowed to establish and operate in the country, must comply with the conditions set by Act 555 that permit their establishment and operation. IPTS are established under the consent of Malaysian Law, thus the implementation and services provided must comply with the conditions set forth in the Act which allowed its establishment. This is in line with the establishment of the national educational philosophy for higher education that aims to integrate the importance of knowledge and the influence of political culture of local community in higher education agenda to produce well-balanced graduates.

Thus, the education system in Malaysia including IPTS must achieve the goals set by National Education Philosophy and possess students with intelligent and sound characteristics as required. To produce students who meet the National Education Philosophy objectives, then two components must be experienced by the students, which are the nation's history and philosophy of knowledge. Discrepancies in compulsory subjects taken by IPTA and IPTS students also affect the establishment of dualism in the national education system. Similarly, the term "compulsory subject" also affects students' psychology, which in their perception, is burdensome, boring and irrelevant to the program they took. Thus, general studies have been revamped to meet the National Education Philosophy and students' Soft Skills.

\section{Legislative Jurisdiction}

The operation of Private Higher Educational Institutions (IPTS) is subject to the Private Higher Educational Institutions Act 1996 which is known as Act 555 which serves to regulate the establishment, registration, management and supervision as well as monitoring the quality of education provided by IPTS.

Based on the original provisions provided under section 43, all IPTS must teach the following subjects:

(a) Malaysian Studies;

(b) Subjects related to the teaching of Islamic Education for Muslim students; and

(c) Moral Education for non-Muslim students.

Section 43 of the original Act 555 also states that the compulsory subject is to be taken by international students in IPTS. However, it is not a mandatory requirement for graduation. Amendments to section 43 of Act 555 (Act A1352/2009) which came into force on June 1, 2009 have authorized the Chief Registrar to set a compulsory subject without stating specifically the types of compulsory subject. This will provide flexibility in prescribing compulsory subjects for IPTS, in line with current developments and needs. Provisions in Section 43 do not mention about the authority of the Chief Registrar to provide exemption to international students. Therefore, it can be assumed that international students are required to take the compulsory subjects.

According to Section 21, IPTS in Malaysia can be classified into 3 groups: 1) Local private educational institutions with University or University College status; 2) branch campuses for those local University or University College; 3 ) branch campuses of foreign universities or university colleges. This means that the establishment of these IPTS is subjected to the consent and requirements of this country. Thus, all of those IPTS, regardless of its form, for as long as it is allowed to establish and operate in the country must comply with the conditions set by Act 555 that permit its establishment and operation. IPTS is established under the consent of Malaysian Law, thus the implementation and services provided must comply with the conditions set forth in the Act which allowed its establishment.

\section{The Old Structure of General Studies}

The old structure of compulsory courses in IPTS is as follows:

1) Malaysian Studies,

2) Islamic Education only for Muslim students,

3) Moral Education only for non-Muslim students,

4) National language

a. All four compulsory courses above are mandatory for local students

b. All four compulsory courses above are exempted for foreign students

Based on the above structure, all students must take the compulsory subjects as the graduation requirement. However, international students are exempted from taking these compulsory subjects. These compulsory subjects must only be taken once by local students throughout their study whether at certificate, diploma or bachelor's 
degree level. This shows that if students have taken these general subjects at certificate level, then they are no longer required to take the subjects at diploma or bachelor's degree level.

\section{The New Structure of General Studies}

The rationales behind the decision for the students to take these university courses under this new structure where Compulsory Subjects (MPW) is changed to General Subjects (MPU) are:

1) Discourses in press that discuss the waning patriotism among IPT students, especially in IPTS.

2) The absence of the uniformity of the teaching of university compulsory courses between IPTS and IPTA has been identified as the main reason for this trend to occur.

3) International students, who have developed this country to become harmonious, stable and progressive also expressed their desire to learn the experience of Malaysia.

4) Teaching and learning of university courses have been adopted by all countries and the subjects should be taken by all local and foreign students.

In order to meet the requirements outlined by the Malaysian Qualifications Agency (MQA) and the National Council on Higher Education Act, where 15-20 percent of overall program consisting of 120 credit to be allocated to university compulsory courses, namely MPU. For that purpose, students must take at least 6 courses worth 3 credits. Thus, $6 \times 3=18$ credits. This sum of 18 credits is equivalent to 15 percent from the whole program $(18 / 120 \times 100=15$ percent $)$.

The proposed restructuring of General Studies must begin with the understanding and improvements to the pillar of knowledge in this country. The pillar of knowledge for MPU in IPTS covers:

1) National Education Philosophy;

2) Nation's Social Historiography Knowledge;

3) Philosophy of Knowledge.

National Education Philosophy refers to "Education in Malaysia is an on-going effort towards further developing the potential of individuals in a holistic and integrated manner, so as to produce individuals who are intellectually, spiritually, emotionally and physically balanced and harmonic, based on a firm belief in and devotion to God. Such an effort is designed to produce Malaysian citizens who are knowledgeable and competent, who possess high moral standards and who are responsible and capable of achieving high level of personal well-being as well as being able to contribute to the harmony and betterment of the society and the nation at large".

According to the Curriculum Development Centre, National Education Philosophy aims to produce good and perfect individuals who will become good citizens and have the following characteristics:

1) Believe and obey God's commands;

2) Knowledgeable;

3) Competent;

4) Have high moral;

5) Have high personality;

6) Willingness to contribute to the community, religion, race and country;

7) Responsible for himself, religion, race, society and the country.

Nation's Social Historiography Knowledge refers to the three pillars of Malaysian civilization which were formed in order to maintain solidarity and progress among people of various groups so that social cohesion is established towards building national unity and integration, namely:

1) The practice of democracy is carried out within the framework of power sharing to ensure political stability.

2) Development of a market-based economy tied to the distribution mechanism in order to maintain social justice.

3) Managing the ethno-religious, extremist and militant based on the law and the Constitution in order to maintain security and public order.

The Philosophy of Knowledge refers to the process of searching the basis and nature of science. It is related to the origins, structure, methods and verification of humanities and social sciences. A sequence of three major 
components in the construction of knowledge is humanitarian, natural sciences, social sciences, which refers to the following three items:

1) Epistemology:

The origins and layout of knowledge.

2) Ontology

The real and the abstract reality of knowledge and its impact on research.

3) Methodology

Research methods based on epistemology and ontology.

The implementation of general studies strategy covers four groups:

U1. Appreciation of the philosophy, values and history,

U2. Mastery of soft skills,

U3. Expansion of knowledge,

U4. Community management skills.

General Study courses are based on the previous Philosophy of Knowledge and involve the scientific fields of Humanity studies, Natural Sciences and Social Sciences. This will enable students to learn the discipline of Humanities, Natural Sciences and Social Sciences to master the content of General Study courses.

University Courses aim to provide students with relevant competencies, which include:

1) Appreciation of The National Education Philosophy based on noble values and history;

2) The ability to think and communicate creatively and critically by using quantitative and qualitative skills;

3) Extensive knowledge in various skills.

4) Co-curricular or community management.

In addition to gaining exposure to intellectual competencies, university courses also serve as complimentary courses to the courses offered in students' specialization. To graduate, students must pass all the university courses.

The structure of MPU courses offered is:

i. U1: Appreciation of educational philosophy based on noble values and history where the students should take at least 2 courses which are equivalent to 4-6 credits. Two of these courses vary according to local and foreign students as follows:

- Malaysian Studies 3 and Malay Language for Communication 2 - 2-3 credits (Compulsory for foreign students)

- TITAS and Ethnic Relations- 2-3 credits (Compulsory for local students)

ii. U2: Mastery of Soft Skills where students are required to take at least 1 course that is equivalent to 2-3 credits. It is compulsory for local and foreign students and among examples of courses to be taken are as follows:

- Leadership Skills and Human Relations

- Invention and Innovation Skills

- Writing skills

- Emotional Management Skills

- Decision Making Skills

- Thinking Skills

- Entrepreneurial Skills

- Or other courses recommended by the Ministry of Education and IPTS

iii. U3: Extensive knowledge in various fields, where students have to take at least 1 course which is equivalent to 2-3 credits. It is compulsory for local and foreign students and among examples of courses to be taken are as follows:

- Malaysian Economic 
- Malaysian Government and Public Policy

- Organizational Behaviour in Malaysian Multi Ethnic Community

- Malaysian Banking and Finance

- Malaysian Work Sociology and Industry

- Malaysian Constitution and Society

- Comparative Religion

- Comparative Ethics

- Malaysian Architecture

- Or other courses recommended by the Ministry of Education and IPTS

iv. U4: Co-curricular or Community Management where students are required to take at least 1 course that is equivalent to 2-3 credits. It is compulsory for local and foreign students and among examples of courses to be taken are as follows:

- Community Service

- Or other courses recommended by the Ministry of Education and IPTS

\section{Islamic Civilization and Asian Civilization Course on UKM and IPTS TITAS Course Outline in UKM}

(1) Course Name: Islamic Civilization and Asian Civilization

(2) Course Code: ZZZT2163

(3) Credit/Contact Hour: 3

(4) Course Status: University Course

(5) Student Learning Time (SLT): 3.075

(6) Learning Outcomes:

1) Students can list the main concepts of Islamic Civilization and Asian Civilization

2) Students can state the importance and the role of their respective religion and culture in life

3) Students are able to communicate effectively in writing and orally at individual, group and community levels.

(7) Synopsis:

This course discusses civilizational studies which include the introduction to civilizational studies, interaction between various civilizations namely Malay, Chinese and Indian, Islam in Malay civilization, contemporary issues relating to Islamic civilization and Asian civilization, Islam Hadhari and the process of nation development.

(8) Pre-requisites: None

(9) References:

Al-Buti, M. S. R. (2004). Islam Hadhari dalam Pembangunan Insan (Asas kepada Pelaksanaan Islam Hadhari di Malaysia) Terj. Muhammad Ramzi bin Omar. Putrajaya: Yayasan Islam Hadhari.

Tinggi, K. P. (2009). Modul Pengajian Tinggi Islam dan Tamadun Asia. Kuala Lumpur: Penerbit Universiti Malaya.

al-Attas, S. M. N. (1971). Islam dan Sejarah Kebudayaan Melayu. Bangi: Universiti Kebangsaan Malaysia.

Universiti Malaya. (2001). Tamadun Islam dan Tamadun Asia. Kuala Lumpur: Penerbit Universiti Malaya.

Mohamad, Z., Yunos, N., \& Haron, M. S. (2006). Tamadun Islam dan Tamadun Asia. Bangi: Pusat Pengajian Umum, Universiti Kebangsaan Malaysia.

(10) Lecture Titles:

1. Introduction of Civilization

2. Inter-Civilization Interaction

3. Islam in Malay Civilization of Malaysia

4. The Influence of Globalization on Civilization 


\section{Western Hegemony and Globalization}

6. Human and Environment

7. The issue of Jihad and Terrorism

8. Economic Jihad

9. Al-Qur'an and Science

10. Ethics of Science Activities

11. Islam Hadhari

\section{TITAS Course Outline in IPTS}

\subsection{Synopsis}

This course discusses civilizational studies which include the introduction to civilizational studies, interactions between various civilizations namely Malay, Chinese and Indian, Islam in Malay civilization, contemporary issues of Islamic civilization and Asian civilization, Islam Hadhari and the nation development process. The objective of this course is to introduce students to the knowledge of civilization which include the introduction to civilizational studies, interactions between various civilizations, contemporary issues and their implications for the country's development process as well as to produce students who have respect for each other, who practise good values and possess the identity of Malaysian citizens.

\subsection{Learning Outcomes}

At the end of this course, students will be able to:

- List main concepts of Islamic Civilization and Asian Civilization

- Explain the importance and the role of their respective religion and culture in life

- Apply effective communication in writing and orally at individual, group and community levels.

\subsection{Syllabus Contents}

Table 1.

\begin{tabular}{lll}
\hline Chapter & Lecture title & Content \\
\hline 1 & Introduction to Civilization & 1) Concept of Civilization \\
& & 2) Inter-civilization Interaction \\
& 3) Inter-civilization Dialogue \\
& 1) Universal view of Islamic Civilization \\
& 2) Concept, Source and Basis \\
& Islamic Civilization & 3) Birth, development and decline \\
& 4) Principles and Characteristics \\
& 5) Contribution of Islamic civilization and Jihad \\
& 1) Concepts \\
& 2) Basis \\
& 3) Universal Views \\
& 4) Achievements \\
& 1) Concepts \\
& 2) Regional and Community \\
& 3) Universal Views \\
& & 4) Religious Diversity \\
& & 5) The role of Islam in Indian Civilization \\
& 6) Achievements \\
& & 1) Concepts \\
& & 2) Regional and Community \\
\hline
\end{tabular}




\begin{tabular}{ll}
\hline Chapter $\quad$ Lecture title & Content \\
\hline & 3) Universal Views \\
& 4) Diversity of Philosophy and Religion \\
& 5) Political Institutions, System of Governance and Family \\
& 6) Achievements \\
& 1) Multiple World Civilization \\
& 2) The Challenge of Globalization \\
Current Issues and Future Challenges & 3) The Clash of Civilizations Theory \\
& 4) Civilization Dialogue \\
& 5) Inculcation of Common Values \\
& 6) Issues in Civilization Dialogue \\
\hline
\end{tabular}

\subsection{Main References}

Tinggi, K. P. (2009). Modul Pengajian Tamadun Islam dan Tamadun Asia. Kuala Lumpur: Universiti Malaya Publisher.

Latif, A. Z. A., \& Aros, A. H. D. A. M. (2012). Tamadun Islam dan Tamadun Asia. Shah Alam: Oxford Fajar

Al-Buti, M. S. R.. (2004). Islam Hadhari dalam Pembangunan Insan (Asas kepada Pelaksanaan Islam Hadhari di Malaysia) Terj. Muhammad Ramzi bin Omar. Putrajaya: Yayasan Islam Hadhari.

al-Attas, S. M. N. (1971). Islam dan Sejarah Kebudayaan Melayu. Bangi: Universiti Kebangsaan Malaysia.

Universiti Malaya. (2001). Tamadun Islam dan Tamadun Asia. Kuala Lumpur: Universiti Malaya Publishe.

Mohamad, Z., Yunos, N., \& Haron, M. S. (2006). Tamadun Islam dan Tamadun Asia. Bangi: General Studies Center, Universiti Kebangsaan Malaysia.

\section{Consolidation of the Elements of Science and Technology}

In UKM, the elements of science and technology for TITAS course are covered directly. Among the topics covered are human and the environment, al-Quran and science and ethics in scientific activities. These topics describe the contribution of Islamic civilization to world civilization. However, in the book entitled "Module for Islamic Civilization and Asian Civilization Studies" published by UM publisher and approved by the Ministry of Higher Education, presently Ministry of Education, the contribution and role of Islamic civilization only covered matters concerning faith, social, economic, political, scientific and art. The elements of science and technology were untouched, while in fact Islamic civilization had contributed and played a very big role in world civilization as a whole. Therefore, it is proposed that the aspects of science and technology elements such as concept and philosophy, character, ethics, figures, institutions, books, contributions and role in physics, chemistry, biology, engineering, architecture, botany, medicine, zoology, etc are also to be introduced.

\section{Conclusion}

Based on the above discussions, it is clearly evident that this MPU could further strengthen the field of Islamic and Asian civilization. It is also suggested that the role and contribution of science and technology in the Islamic civilization to world civilization to be adopted in the TITAS course to achieve the course's goal namely to introduce students to the science of civilization which includes the introduction to civilizational studies, interactions between various civilizations, contemporary issues and their implications for the country's development process as well as to produce students who have respect for each other, who practise good values and possess the identity of Malaysian citizens.

\section{References}

Alias, J., Muslim, N., Mansor, A. Z., Salleh, R., \& Basir, A. (2012). Generic Skills Courses In Fulfilling The Requirement Of The Malaysian Qualification Framework: A Study On Universiti Kebangsaan Malaysia Students. Journal of Applied Sciences Research, 8(5), 2608-2619.

Buntat, Y. (2004). Integrasi Kemahiran "Employability" in the Industrial and Agricultural Vocational Education in Malaysia. Universiti Teknologi Malaysia: PhD Thesis.

Ismail, R. (2007). Pembangunan Sumber Manusia Dalam Era k-Ekonomi. Bangi: UKM Publisher.

Malaysia. (2006). Rancangan Malaysia Kesembilan 2006-2010. Kuala Lumpur: Economic Planning Unit. 
Mohamad, A. H. (2000). Konsep Kemahiran Berfikir: Pengertian Kemahiran Berfikir. Putrajaya: Curriculum Development Center.

Mohamad, Z., \& Said, A. A. D. N. E. M. (2011). Perbandingan Kemahiran Generik Pelajar Opsyen Bahasa Melayu di Sebuah IPTA dan IPGM. ASEAN Journal of Teaching \& Learning in Higher Education, 4(1), 82-95.

Mohamad, Z., Yunos, N., \& Haron, M. S. (2006). Tamadun Islam dan Tamadun Asia. Bangi: Pusat Pengajian Umum, Universiti Kebangsaan Malaysia.

Muslim, N. (2012). An Analysis on The Perception and Image of Prestigious Public Higher Learning Institutions (IPTA) in Malaysia From Development Perspective. Journal of Applied Sciences Research, 8(7), 3277-3283.

Muslim, N., \& Yunus, J. T. D. N. (2011). Keberkesanan Pengajaran Kursus Generik di UKM dan Peranannya Dalam memenuhi Keperluan Kerangka Kelayakan Malaysia. In D. A. Zainal, J. Mapjabil, \& M. S. D. M. Z. E. Othman (Eds.), Kemahiran dan Kecekapan Dalam Pendidikan. Minden: Penerbit USM.

Muslim, N., Alias, J., Mansor, A. Z., Salleh, A. R., \& Basir, A. (2012). Viewpoint of Students of National University of Malaysia on Generic Skill Courses. World Applied Sciences Journal, 18(6), 754-761.

Samian, A. L., \& Haron, N. M. D. H. (2012). Sains dan Teknologi di Alam Melayu. Bangi: ATMA.

Tinggi, K. P. (2006). Modul Pembangunan Kemahiran Insaniah (Soft Skills) Untuk Institusi Pengajian Tinggi Malaysia. Serdang, Selangor: Universiti Putra Malaysia.

Tinggi, K. P. (2009). Modul Pengajian Tamadun Islam dan Tamadun Asia. Kuala Lumpur: Universiti Malaya Publisher.

\section{Copyrights}

Copyright for this article is retained by the author(s), with first publication rights granted to the journal.

This is an open-access article distributed under the terms and conditions of the Creative Commons Attribution license (http://creativecommons.org/licenses/by/3.0/). 